\title{
Multidisciplinary investigation of identity of the "Areni” grape variety
}

\author{
Nelli Hovhannisyan ${ }^{1}$, Marina Dallakyan ${ }^{1}$, Aleksandr Yesayan ${ }^{1}$, Tamara Bagoyan², Gagik Melyan ${ }^{3}$, and Boris Gasparyan ${ }^{2}$ \\ ${ }^{1}$ Center of Excellence in Applied Biosciences, Yerevan State University, 1 Alex Manoogian str., 0025 Yerevan, Republic \\ of Armenia \\ ${ }^{2}$ Institute of Archaeology and Ethnography, National Academy of Sciences of the Republic of Armenia, 15 Charents str., \\ 0025 Yerevan, Republic of Armenia \\ ${ }^{3}$ Scientific Center of Viticulture, Fruit-Growing and Wine-Making, Armavir Marz, 378312 Merdzavan vil., Republic of \\ Armenia
}

\begin{abstract}
Having centuries-old tradition in viticulture and winemaking Armenia characterized with high ampelographic diversity of grape local autochthonous and modern cultivars. Meantime, the world's earliest known wine-making facility has been discovered during the excavation of Areni-1 cave dating back to 6000 years (the beginning of the IV Millennium BCE). In parallel, among huge diversity of wine grapes the so called "Areni" variety is one of the most famous, used for red wine production by majority of the winemaking companies and local farms nowadays. A combination of genetic, ampelographic and archaeological data allows us to come to preliminary conclusion that as a true to type "Sev (Black) Areni" variety can be considered the one which is growing in old "Vankapatkan" vineyards of Vayots Dzor and in grape collection of the Scientific Center of Fruit Growing, Viticulture and Wine-making in Armenia (accession N42). The "Seyrak Areni" (70) should not be considered as a synonym of "Sev (Black) Areni". In this study we tried to highlight also the importance of combination of the generated data from ancient and modern grape multidisciplinary investigations.
\end{abstract}

\section{Introduction}

Viticulture and winemaking played important role in economy, social and cultural life in Armenia starting from the timing of formation of the complex societies, which chronologically corresponds to the so-called Late Chalcolithic period. The world's earliest known wine-making facility has been discovered during the excavation of Areni-1 cave in 2007 dating back to 6000 years (the beginning of the IV Millennium BC), also confirmed by archaechemical analyses [1].

Having centuries of old tradition in viticulture and winemaking Armenia characterized with high ampelographic diversity of grape local autochthonous and modern cultivars. According to the literary data until 1990s Armenian Merdzavan ampleogarphic collection used to contain more than 800 grape autochthonous and introduced varieties $[2,3]$. Unfortunately, after the privatization it was fully destroyed and currently holds less than 100 accessions. According to references, there are more than 400 native varieties among which only $70(17.5 \%)$ are preserved in the collection. All these led to marked genetic erosion with the consequent risk of loss of the germplasm. However, the ampelographic descriptions of most varieties are available, including agronomical and technological aptitudes and, and also some of the local varieties growing in small farms. Among huge diversity of wine grapes the so called "Areni" variety is one of the most famous used for red wine production by majority of the winemaking companies and local farms. Historically it is originating from the Vayots Dzor Region in southeastern Armenia. "Areni" variety is known from the local ampelography as "Sev (Black) Areni" [2] and has 39 synonyms in VIVC database (www . vivc. de).
As part of our study on characterization of the existing autochthon, old, long-neglected and endangered grapevine cultivars in Armenia and during the inventory of grape genetic resources the presence in the vineyards of "Sev Areni" varieties with different names like "Areni", "Areni Yeghegisi", "Areni Vaghahas" was identified.

Observations on accessions growing in Vayots Dzor private vineyards, as well as in Merdzavan grape collection, and also having the same or a similar name in the inventory showed that the morphological characteristics of this variety were different, although some morpho-physiological traits of berry and bunch were in common. Hence the study to identify the true-to type "Areni" was set up, with an idea to implement comparative interdisciplinary investigations on accessions from different modern vineyards in Vayots Dzor (Areni (43), Areni (44), Areni (45) Areni Yeghegisi (46), Areni Vaghahas (4)), modern growing grape varieties from national grape collection of the Scientific Center of Fruit Growing, Viticulture and Wine-making (Areni (42), Seyrak Areni (70)) and from old "Vankapatkan" vineyards (old vineyards in the vicinity of the Medieval Noravank Monastic Complex) (Areni Vankapatkan (15), Areni Vankapatkan D (74), Areni Vankapatkan F (75), Areni Vankapatkan G (76). Moreover, we added to this comparison ${ }^{14} \mathrm{C}$ dated medieval grape branch (780-1000 Cal AD) [4] from Areni 1 cave (Vitis-6).

\section{Materials and methods}

Samples of 13 accessions were analyzed in triplicate. The genetic analyses were implemented at Yerevan State University (Armenia). Genomic DNA was isolated 
according to the protocol for DNeasy Plant Mini Kit (Qiagen, Hilden, Germany).

The aDNA extractions and PCR setup for medieval grape were performed in a dedicated ancient DNA laboratory at Yerevan State University, where appropriate measures are taken to prevent contamination with modern sources of DNA. The grape steam was washed in commercial bleach solution and rinsed with ultrapure water few times. To remove external contaminant sources of

Table 1. Genetic parameters for 23 SSR loci analyzed for 14 Armenian "Areni" grape cultivars.

\begin{tabular}{|l|l|l|l|l|l|}
\hline \multicolumn{1}{|c|}{ Locus } & \multicolumn{1}{|c|}{ Na } & \multicolumn{1}{|c|}{ Ne } & \multicolumn{1}{|c|}{ Ho } & He) & PI \\
\hline VRZAG62 & 11.000 & 6.145 & 1.000 & 0.837 & 0.04 \\
\hline VRZAG79 & 8.000 & 4.629 & 0.889 & 0.784 & 0.07 \\
\hline VVIV67 & 8.000 & 4.414 & 0.875 & 0.773 & 0.08 \\
\hline VVS2 & 9.000 & 4.694 & 0.154 & 0.787 & 0.07 \\
\hline VMC1B11 & 7.000 & 3.390 & 1.000 & 0.705 & 0.13 \\
\hline VVIN16 & 5.000 & 1.635 & 0.182 & 0.388 & 0.39 \\
\hline VVIN73 & 5.000 & 1.538 & 0.200 & 0.350 & 0.44 \\
\hline VVIP60 & 6.000 & 1.833 & 0.182 & 0.455 & 0.32 \\
\hline VVMD25 & 7.000 & 3.951 & 1.000 & 0.747 & 0.10 \\
\hline VVIB01 & 9.000 & 4.962 & 0.357 & 0.798 & 0.07 \\
\hline VVIH54 & 8.000 & 5.026 & 0.286 & 0.801 & 0.06 \\
\hline VVMD5 & 9.000 & 5.714 & 0.700 & 0.825 & 0.05 \\
\hline VrZAG67 & 5.000 & 3.282 & 1.000 & 0.695 & 0.14 \\
\hline VVIQ52 & 6.000 & 4.122 & 0.923 & 0.757 & 0.10 \\
\hline VVMD27 & 8.000 & 3.698 & 0.929 & 0.730 & 0.11 \\
\hline VVMD32 & 9.000 & 3.136 & 0.643 & 0.681 & 0.12 \\
\hline VrZAG83 & 4.000 & 1.502 & 0.154 & 0.334 & 0.46 \\
\hline VVIP31 & 9.000 & 5.452 & 1.000 & 0.817 & 0.06 \\
\hline VVIV37 & 9.000 & 6.128 & 1.000 & 0.837 & 0.05 \\
\hline VVMD24 & 8.000 & 4.102 & 0.818 & 0.756 & 0.09 \\
\hline VVMD7 & 5.000 & 1.779 & 0.154 & 0.438 & 0.35 \\
\hline VMC4f3.1 & 10.000 & 6.541 & 0.727 & 0.847 & 0.04 \\
\hline VVMD21 & 6.000 & 3.556 & 0.375 & 0.719 & 0.12 \\
\hline Cumulative & 171.000 & 91.228 & 14.547 & 15.862 & \\
\hline Vean & 7.435 & 3.966 & 0.632 & 0.690 & \\
\hline VE & 0.324 & 0.073 & 0.035 & \\
\hline VI92 & & & & \\
\hline VIS & & & & \\
\hline
\end{tabular}

DNA, the seeds were briefly washed in dilute bleach solution (10\% commercial strength) then rinsed in analytical grade $\mathrm{H}_{2} \mathrm{O}$. Further the DNA was extracted using DNeasy Plant Mini Kit (Qiagen, Hilden, Germany) modified by us. The extraction was done in triplicate, four extraction controls were performed to monitor any external or cross contamination.

23 polymorphic microsatellites considered as the most appropriate to evaluate the grapevines (European projectGENRES081, http : / / www.genres.de/vitis) were used. VMC1B11 [5]; VMC4F3.1 [6]; VrZAG62, VrZAG67 and VrZAG79 [7]; VVIB01, VVIH54, VVIN16, VVIN73, VVIP31, VVIP60, VVIQ52, VVIV37, VVIV67 [8]; VVMD5, VVMD7, VVMD21, VVMD24, VVMD25, VVMD27, VVMD28 and VVMD32 [9]; VVS2 [10]. The Type IT Microsatellite Kit (Qiagen) were used to set up reaction mixtures containing master mix, 100 pmol of each primer and about $1 \mathrm{ng}$ of template DNA. Amplification was performed in TC 5000 Thermal Cyclers (Thechne), using the following program: 3 minutes initial denaturation at $95^{\circ} \mathrm{C}$, followed by 30 cycles of denaturation at $95^{\circ} \mathrm{C}$ (15 seconds), annealing at $60^{\circ} \mathrm{C}$ (30 seconds) and extension at $72^{\circ} \mathrm{C}$ (30 seconds). A final extension was performed at $72^{\circ} \mathrm{C}$ for 7 minutes. DNA of two certified reference varieties of "Muscat á petits grains" and "Cabernet franc" were amplified and used for data comparison.

The fragment length determination and analyzes was done by capillary electrophoreses in Qiaxcel Genetic Analyzer (Qiagen). Peaks were identified by size and height with Biocalculator Software (Qiagen). The mean number of alleles per locus $(\mathrm{Na})$, number of effective alleles $(\mathrm{Ne})$, levels of observed $(\mathrm{Ho})$, and expected $(\mathrm{He})$ heterozygosity, as well as probability of identity, and Principal Coordinates Analyses (PCoA) were calculated using GenAlEx 6.5 [11,12]. The neighbour-joining analyses were conducted using MEGA version 6 [13].

\section{Results and discussion}

The sampling strategy which includes varieties growing within modern vineyards, old vineyards and collection gardens, as well as ancient grape remains identified in the same region and the analysis of 23 microsatellites allowed to determine true-to-type "Areni" cultivar. All the accessions of the grape "Areni" were firstly genotyped at 23 microsatellite loci. Vouillamoz et al. (2006) suggested analyzing independent samples to clear up the dilemma of true to type "Sev Areni" variety [14].

Among the analyzed accessions 171 alleles were generated at 23 microsatellite markers. The number of alleles per locus ranged from 5 (VVIN16, VVIN73, VrZAG67, VVMD7) to 11 (VRZAG62) with a mean number of 7.435 (Table 1). According to this data the most informative alleles were VRZAG62 (6.145), VMC4f3.1 (6.541), VVIV37 (6.128).

13 microsatellites were recovered from medieval grape steam DNA, which demonstrates the perfect state of nuclear DNA preservation. No extraction and PCR controls showed any example of cross contamination. The generated microsatellite data allow to perform tentative comparison of the medieval grape genetic profile with the modern varieties, which gave additional data on identification of 
"Areni" variety. In general from 6 to 22 microsatellites are required to fully resolve the cultivar for modern grape samples [14-16]. The successful amplification of 5 SSR markers from an ancient DNA extracted early and late medieval grape seeds was reported by Cappellini et al. (2010). In our investigation we used steam to extract DNA instead of the seeds, because though $V$. vinifera is a hermaphrodite the crosses cannot be excluded, and consequently, analyses of ancient wood remains would also be useful to characterize old cultivars and compare their DNA profiles with those from modern ones [17,18].

The expected and observed heterozygosity values were relatively high, with average at 0.632 and 0.690 accordingly.

From the data obtained in the examined accessions the $\mathrm{Ho}$ was lower than the $\mathrm{He}$ for the $50 \%$ of SSR loci analyzed which in general indicating probable inbreeding, and in our case the fact of common origin and clonal propagation among the varieties.

However as it is shown in Table 1 , for the 11 loci (VRZAG62, VRZAG79, VVIV67, VMC1B11, VVMD25, VrZAG67, VVIQ52, VVMD27, VVIP31, VVIV37, VVMD24) analyzed the $H o$ was higher than $H e$, and was 0.949 and 0.767 accordingly). Such a high rate of heterozygosity is commonly observed among outbreeding, perennial species [19]. In our case it might be linked with the fact different allelic combinations, high mutation rates within the analyzed accessions [20].

The PI value estimates the probability that two unrelated (randomly sampled) individuals will have an identical genotype for each single SSR marker analyzed, or for a whole set of SSR markers. Total probability of identity (PI) was ranging from 0.04 to 0.45 and the expected number of individuals with the same multilocus genotype for Increasing Locus Combinations (calculated as respective probability $\times$ population size) was very low and was $1.1 \mathrm{E}-21$, which prove the high discriminating power of the selected SSR loci.

Neighbour joining tree was constructed based pairwise population Nei's Genetic Distance in order to analyze genetic relationships between studied accessions. Two distinct clusters were isolated. In the first cluster Areni (43), Areni (44), Areni (45), Areni Yeghegisi (46),
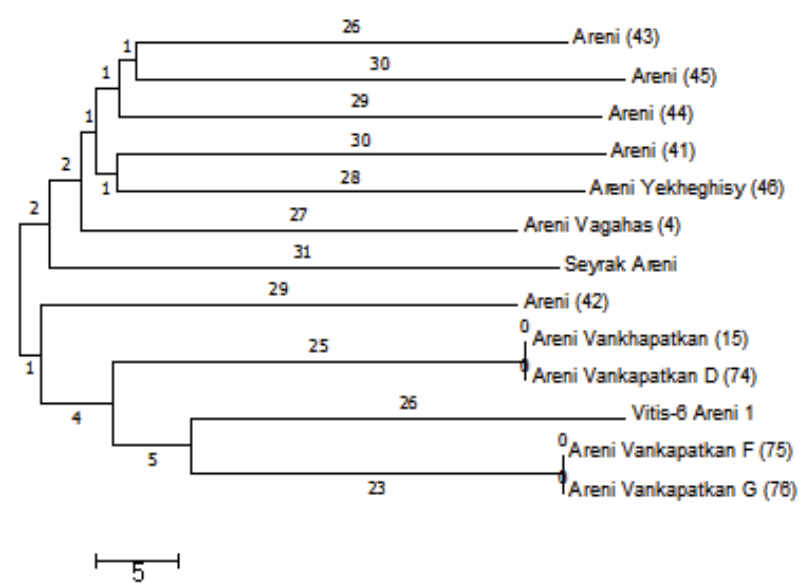

Figure 1. Neighbour-joining tree of 14 grape accessions. Every accession is shown with its accession number.

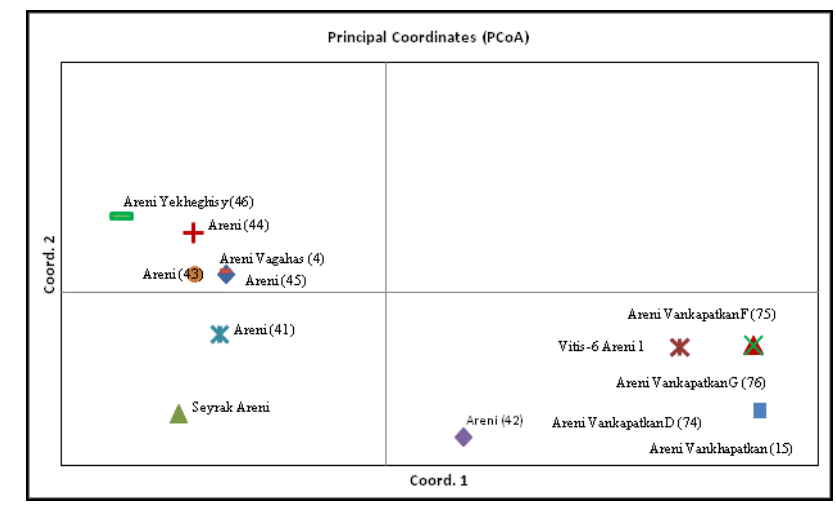

Figure 2. Principal coordinates analysis of 14 grape accessions analyzed with 23 SSR loci plotted on the first two coordinates.

Areni Vaghahas (4) which are very close to each other and Seyrak Areni (70) has the were included and in the second cluster Areni (42) (national grape collection) and Areni Vankapatkan D (74), Areni Vankapatkan F (75), Areni Vankapatkan G (76), Areni Vankapatkan (15) and Medieval Vitis-6 were merged.

It should be mentioned that Areni Vankapatkan 15 and 74 and Areni Vankapatkan 75 and 76 are absolutely identical and very close to each other. These accessions are very close to Medieval Vitis -6 excavated from Areni -1 cave. Areni (42) from national grape collection of the Scientific Center of Fruit Growing, Viticulture and Winemaking identified in the second cluster, which genetically really close to the medieval grape and grapes growing in Vankapatkan Vineyards.

The first two coordinates of the PCoA, accounting for 31.95 and $35.21 \%$ of the total variation, differentiated the samples into two main clusters: (i) the group clusterizing the Areni grapes collected from the Vankapatkan vineyards (the vineyards in the vicinity of the Noravank Monastic Complex), as well as Medieval grape from the Areni- 1 cave and one accession of Areni collected from national collection; and (ii) all the varieties from the commercial vineyards and Seyrak Areni from the national grape collection of the Scientific Center of Fruit Growing, Viticulture and Wine-making.

\section{Conclusion}

A combination of genetic, ampelographic and archaeological data, allows as to come to preliminary conclusion that as a true to type "Areni" or "Sev (Black) Areni" variety can be considered the ones which are growing in old Vankapatkan vineyards of Vayots Dzor and in grape collection of the Scientific Center of Fruit Growing, Viticulture and Wine-making in Armenia (accession N42).

The genetic distance analyses and PI data shows that Vitis-6 is closely related to grapes collected from Vankapatkan vineyards and Areni (42) from the grape collection. This allows to assume that medieval Vitis- 6 might be considered as one of the possible progenitors of modern "Areni" and other varieties.

The Seyrak Areni (70) is genetically different from Areni (42) which is considered as a true to type Sev Areni. This means that Seyrak Areni should not be considered as 
a synonym of "Sev Areni" as it is mentioned in VIVC database, but should be leaved as a separate rare variety which is genetically close to Areni, as it is mentioned in Armenian Ampleography [2]. In this study we have tried to highlight also the importance of combination of data generated from ancient and modern grape multidisciplinary investigations.

The study was supported by the Armenian SCS project 13-1F237 project "archaeogenetic investigation of ancient grape remains from Areni cave"

\section{References}

[1] H. Barnard, A. Dooley, G. Areshian, B. Gasparian, K. Faull, J Archaeol Sci 38, 5, 977-984 (2010)

[2] M. G. Tumanyan (Ed.), Ampelography of Armenian SSR. (Armenian Academy of Sciences Press, Yerevan, 1947) (in Armenian)

[3] S. Gasparyan and G. Melyan, Condition and prospects preservation of genetic resources of grapes on Armenia. Report at the international conference 'Retention and the Use of Genetic Resources of the Grapevine of the Caucasus and North Black Sea Area', Tbilisi, Georgia, 15 October (2003)

[4] A. Smith, T. Bagoyan, I. Gabrielyan, R. Pinhasi, B. Gasparyan, Late Chalcolithic and Medieval Archaeobotanical Remains from Areni-1 (Birds' Cave), Armenia, in B. Gasparyan and M. Arimura (Eds.), Stone Age of Armenia, A Guide-book to the Stone Age Archaeology in the Republic of Armenia, Monograph of the JSPS-Bilateral Joint Research Project, Kanazawa University Press, Printed in Japan, 2014, ISBN 978-4-9908070-0-9, 233-260 (2014)

[5] E. Zyprian, R. Topfer, National Center For Biotechnology Information NCBI, Genbank (Bethesda, Maryland, USA, 2005)

[6] G. Di Gaspero, E. Peterlunger, R.Testolin, K. Edwards, G. Cipriani, Theor Appl Genet 101, 301-308 (2000)
[7] K. Sefc, F. Regner, J. Turetschek, J. Glössl, H. Steinkellner, Genome 42, 1-7 (1999)

[8] D. Merdinoglu, G. Butterlin, L. Bevilacqua, V. Chiquet, A. Adam-Blondon, S. Decroocq, Mol Breed 15, 349-366 (2005)

[9] J. E. Bowers, G. S. Dangl, C. P. Meredith, Am. J. Enol. Vitis. 50, 243-246 (1999)

[10] M.R. Thomas, N.S. Scott, Theor Appl Genet 86, 985-990 (1993)

[11] R. Peakall, P.E. Smouse, Mol Ecol Notes, 6, 288-295 (2006)

[12] R. Peakall, P.E. Smouse, Bioinformatics, 28, 2537-2539 (2012)

[13] K. Tamura, G. Stecher, D. Peterson, A. Filipski, S. Kumar, Mol Biol Evol, 30, 2725-2729 (2013)

[14] J.F. Vouillamoz, P.E. Mcgovern, A. Ergul, G. So “Ylemezog ${ }^{\complement L u}$, G. Tevzadze, C.P. Meredith, M. S. Grando, Plant Genet Resour 4, 2, 44-158 (2006)

[15] J. Vouillamoz, D. Maigre, C.P. Meredith, Theor Appl Genet 107, 448-454 (2003)

[16] P. This, A. Jung, P. Boccacci, J. Borrego, R. Botta, L. Costantini, M. Crespan, G. Dangl, C. Eisenheld, F. Ferreira-Monteiro, S. Grando, J. Ibáñez, T. Lacombe, V. Laucou, R. Magalhães, C. Meredith, N. Milani, E. Peterlunger, F. Regner, L. Zulini, E. Maul, Theor Appl Genet 109, 1448-1458 (2004)

[17] P. This, T. Lacombe, M.R .Thomas, Trends Genet 22, 511-519 (2006)

[18] E. Cappellini, M. T. Gilbert, P. F. Geuna, G. Fiorentino, A. Hall, J. Thomas-Oates, P. D. Ashton, D.A. Ashford, P. Arthur, P.F. Campos, J. Kool, E. Willerslev, M.J. Collins, Die Naturwissenschaften, 97, 2, 205-217 (2010)

[19] M.K. Aradhya, G.S. Dangl, B.H. Prins, J.M. Boursiquot, A.M. Walker, C.P. Meredith, C.J. Simon, Genet Res (Camb) 81, 179-192 (2003)

[20] M. Dallakyan, A. Yesayan, N. Hovhannisyan, Ajastan Kensab. Handes 66, 2, 84 (2014) 